九州大学学術情報リポジトリ

Kyushu University Institutional Repository

\title{
Micropropagation of Ornamantal Alocasia
}

\section{Thao, Nguyen Thi Phuong}

Laboratory of Horticultural Science, Division of Agricultural Botany, Department of Plant Resources, Graduate School of Bioresource and Bioenvironmental Sciences, Kyushu University

Miyajima, Ikuo

Ureshino, Kenji

Laboratory of Plant production, Department of Agro-bioscience, Faculty of Agriculture, Iwate University

Ozaki, Yukio

Laboratory of Horticultural Science, Division of Agricultural Botany, Department of Plant Resources, Faculty of Agriculture, Kyushu University

他

https://doi.org/10.5109/4496

出版情報：九州大学大学院農学研究院紀要. 47 (2)，pp.277-282，2003-02-01. Faculty of Agriculture, Kyushu University

バージョン：

権利関係 : 


\title{
Micropropagation of Ornamental Alocasia
}

\section{Nguyen Thi Phuong THAO*†, Ikuo MIYAJIMA**, Kenji URESHINO***, Yukio OZAKI**** and Hiroshi OKUBO}

\author{
Laboratory of Horticultural Science, Division of Agricultural Botany, Department of \\ Plant Resources, Faculty of Agriculture, Kyushu University, \\ Fukuoka 812-8581, Japan \\ (Received October 29, 2002 and accepted November 7, 2002)
}

\begin{abstract}
In vitro multiplication of Alocasia micholitziana 'Green Velvet', Alocasia ×amazonica and Alocasia cuculata was achieved from axillary buds excised from the corms of greenhouse-grown plants. Shoots were developed directly within 6-8 weeks on the MS medium supplemented with $10 \mathrm{mgl}^{-1} 2$-iP for $A$. micholitziana 'Green Velvet' or $10 \mathrm{mgl}^{-1} \mathrm{BA}$ for $A$. $\times$ amazonica and $A$. cuculata. Considering the quality of the shoots, high frequency of shoot regeneration was achieved on similar medium in subsequent subcultures for $A$. micholitziana 'Green Velvet' ( 5.0 shoots/culture). Five $\mathrm{mgl}^{-1} \mathrm{BA}$ gave the best shoot regeneration in $A . \times$ amazonica and A. cuculata (4.6 and 5.0 shoots/culture, respectively). Shoots of the regenerated plants rooted abundantly on the hormone free MS within 4 weeks. Acclimatization was successful with approximately $100 \%$ of the in vitro plantlets which survived in a greenhouse. The regenerated plants seemed morphologically to be similar to the respective mother plants. The established procedure provided a basic technique to carry out the furture in vitro experiments in Alocasia.
\end{abstract}

\section{INTRODUCTION}

Belonging to Araceae family which contains about 120 genera, 2,000 species, Alocasia is one of the largest and most morphologically diverse genus consisting of over than 60 species. They are found mainly in tropical forests of South and Southeast Asia. Plants of this herbaceous monocot are terrestrials or lithophytes, normally evergreen, mainly rhizomatous, sometimes tuber-bearing perennials. The extravagant and exotic features of the foliage make Alocasia suitable for cultivation as valuable ornamental potted plants.

Traditional methods of vegetative propagation of Alocasia such as corm division provide an extremely slow rate of multiplication. Thus, there has been a distinct need to investigate the potential of in vitro propagation systems for this plant, as has been

* Laboratory of Horticultural Science, Division of Agricultural Botany, Department of Plant Resources, Graduate School of Bioresource and Bioenvironmental Sciences, Kyushu University. Present address: Hanoi Agricultural University No. 1, Faculty of Agronomy, Department of Plant Physiology, Gialam, Hanoi, Vietnam.

** Present address: c/o Dr. Ricardo Rojas, JICA Argentine Office, 401 Piso 8, 1001-Buenos Aires, Argentina

*** Present address: Laboratory of Plant Production, Department of Agro-bioscience, Faculty of Agriculture, Iwate University, 3-18-8 Ueda, Morioka 020-8550, Japan

**** Present address: Laboratory of Agricultural Ecology, Faculty of Agriculture, Kyushu University, Kasuya 811-2307 Japan

t Corresponding author (E-mail: thaohau@yahoo.com) 
successfully achieved with other ornamental foliage species in Araceae family (Geier, 1986; Hutchinson et al., 1994; Lin et al., 2000). The development of a rapid mass propagation system through tissue culture would not only be a powerful tool for commercial propagation but also be an important step that will open new avenues for the further breeding research in Alocasia in which modern technologies of molecular genetics would be applied (Broertjes and Van Harten, 1978; Ibrahim et al., 1988). In this study, the feasibility of establishing a protocol for the micropropagation of Alocasia that will be used in further mutation breeding studies was investigated.

\section{MATERIALS AND METHODS}

\section{Plant materials}

Three species/cultivars of Alocasia were chosen for the study including $A$. micholitziana 'Green Velvet', $A$. ×amazonica and $A$. cuculata.

Plants of these species/cultivars were purchased from commercial growers in Japan and kept in a greenhouse of Laboratory of Horticultural Science, Kyushu University for further in vitro research.

\section{Surface sterilization}

Corms of the plants were collected. They were brushed carefully to remove soils with detergent and washed under tap water. After removing the outermost whorl of the petiole, the corms were rinsed with distilled water. Two thirds of the corm was peeled off from the base and the remaining portion was washed again with distilled water. Then it was surface sterilized by stirring in $\mathrm{NaOCl}$ solution (active chlorine $1 \%$ ) containing $0.01 \%$ Tween 20 for 20 minutes. The sterilized corms were washed three times with sterile distilled water. The petiole bases were removed and apical shoots and axillary buds of the corms were excised aseptically. They were cultured on initial medium for shoot proliferation.

\section{Culture medium}

The basal medium was Murashige and Skoog medium (MS; Murashige and Skoog, 1962) supplemented with $30 \mathrm{gl}^{-1}$ sucrose and $8 \mathrm{gl}^{-1}$ agar. Shoot regeneration for $A$. micholitziana 'Green Velvet' was induced with $10 \mathrm{mgl}^{-1} 2$-iP added to the basal medium and for $A$. $\times$ amazonica and $A$. cuculata was with $10 \mathrm{mgl}^{-1}$ BA. For shoot multiplication, $2-\mathrm{iP}$ or BA at various concentrations $\left(0-10 \mathrm{mgl}^{-1}\right)$ was tested. The $\mathrm{pH}$ was adjusted to 5.7 prior to being autoclaved for $15 \mathrm{~min}$ at $121^{\circ} \mathrm{C}$.

\section{Culture conditions}

All cultures were maintained at $25 \pm 2{ }^{\circ} \mathrm{C}$ in continuous light condition $(44.73 \mu \mathrm{mol}$ $\mathrm{sec}^{-1} \mathrm{~m}^{-2}$ ) and subcultured monthly.

\section{Rooting and plantlet regeneration}

Shoots that developed on multiplication media were transferred to hormone free MS medium for rooting. Complete plantlets (shoots with roots) were transplanted to a mixture of $1: 3(\mathrm{v}: \mathrm{v})$ vermiculite and soil in plastic pots and placed in the greenhouse for 
acclimatization.

\section{RESULTS AND DISCUSSION}

\section{Shoot regeneration}

The regeneration of new clean shoots from primary explants is a prerequisite for any micropropagation programme. In this experiment, the pre-existing buds started to develop earliest and new shoot development was observed within eight weeks of their cultures. Explants showing contamination were discarded. Only visibly clean shoots were retained for further propagation.

\section{Effect of cytokinin on the shoot multiplication}

The transfer of primary regenerated shoots onto hormone-free MS medium did not lead to shoot multiplication but they elongated and rooted abundantly.

Shoot multiplication with the reference to the multiplication rate and the shoot quality was significantly affected by genotypes, the types and concentrations of cytokinins applied (Table 1, Fig. 1). Among three species/cultivars, the shoot formation of $A . \times$ amazonica responded poorly on the media containing $2-\mathrm{iP}$ and the best shoot multiplication was recorded on the MS medium supplemented with $5 \mathrm{mgl}^{-1} \mathrm{BA}$.

In case of $A$. micholitziana 'Green Velvet', although no statistical differences in shoot multiplication rate were observed between the MS medium containing $5 \mathrm{mgl}^{-1} \mathrm{BA}$ and $10 \mathrm{mgl}^{-1} 2-\mathrm{iP}$ (on which the highest rate of shoot multiplication were induced), the quality of the shoot was obviously affected by BA. The frequency of abnormal shoot increased with increasing concentrations of BA in the medium. The best medium for the shoot multiplication of A. micholitziana 'Green Velvet' in terms of the number of shoots per culture and shoot quality, therefore, appeared to be MS supplemented with $10 \mathrm{mgl}^{-1} 2-\mathrm{iP}$.

For A. cuculata, the highest shoot multiplication was obtained on MS added with $5 \mathrm{mgl}^{-1} \mathrm{BA}$. The medium with $2-\mathrm{iP}$ at $5 \mathrm{mgl}^{-1}$ showed a slightly lower rate of multiplication but the growth of shoots also appeared to be better than that of the shoots induced on the medium with BA.

Table 1. Effect of cytokinins on shoot multiplication rate in Alocasia

\begin{tabular}{|c|c|c|c|c|c|}
\hline \multirow{2}{*}{$\begin{array}{l}\text { Plant } \\
\text { growth } \\
\text { regulators }\end{array}$} & \multirow{2}{*}{$\begin{array}{l}\text { Concentration } \\
\left(\mathrm{mgl}^{-1}\right)\end{array}$} & \multirow{2}{*}{$\begin{array}{l}\text { No. of } \\
\text { explants } \\
\text { examined }\end{array}$} & \multicolumn{3}{|c|}{ Shoot multiplication rate $($ mean \pm SE) } \\
\hline & & & $\begin{array}{l}A . \text { 'Green } \\
\text { Velvet' }\end{array}$ & $\begin{array}{l}\text { A. } \times \\
\text { amazonica }\end{array}$ & $\begin{array}{l}A . \\
\text { cuculata }\end{array}$ \\
\hline Control & 0 & 27 & $1.1 \pm 0.1 \mathrm{a}^{*}$ & $1.0 \pm 0.0 \mathrm{a}^{*}$ & $1.0 \pm 0.0 \mathrm{a}^{*}$ \\
\hline \multirow[t]{3}{*}{ BA } & 1 & 27 & $4.0 \pm 0.2 \mathrm{c}$ & $3.3 \pm 0.2 \mathrm{c}$ & $4.3 \pm 0.2 c^{*}$ \\
\hline & 5 & 27 & $5.0 \pm 0.2 \mathrm{~d}$ & $4.6 \pm 0.3 \mathrm{~d}$ & $5.0 \pm 0.2 \mathrm{~d}$ \\
\hline & 10 & 27 & $3.8 \pm 0.2 \mathrm{c}$ & $4.7 \pm 0.2 \mathrm{~d}$ & $4.3 \pm 0.2 \mathrm{c}$ \\
\hline \multirow[t]{3}{*}{$2-\mathrm{iP}$} & 1 & 27 & $1.6 \pm 0.1 \mathrm{a}^{*}$ & $1.1 \pm 0.1 \mathrm{a}^{*}$ & $1.3 \pm 0.1 \mathrm{a}^{*}$ \\
\hline & 5 & 27 & $2.8 \pm 0.2 b$ & $1.3 \pm 0.1 \mathrm{a}^{*}$ & $4.4 \pm 0.2 \mathrm{c}$ \\
\hline & 10 & 27 & $5.0 \pm 0.3 \mathrm{~d}$ & $2.6 \pm 0.2 \mathrm{~b}$ & $3.2 \pm 0.2 \mathrm{~b}$ \\
\hline
\end{tabular}

* The treatments that showed root formation. Mean separation by Duncan's multiple range test $(P<0.05)$. 


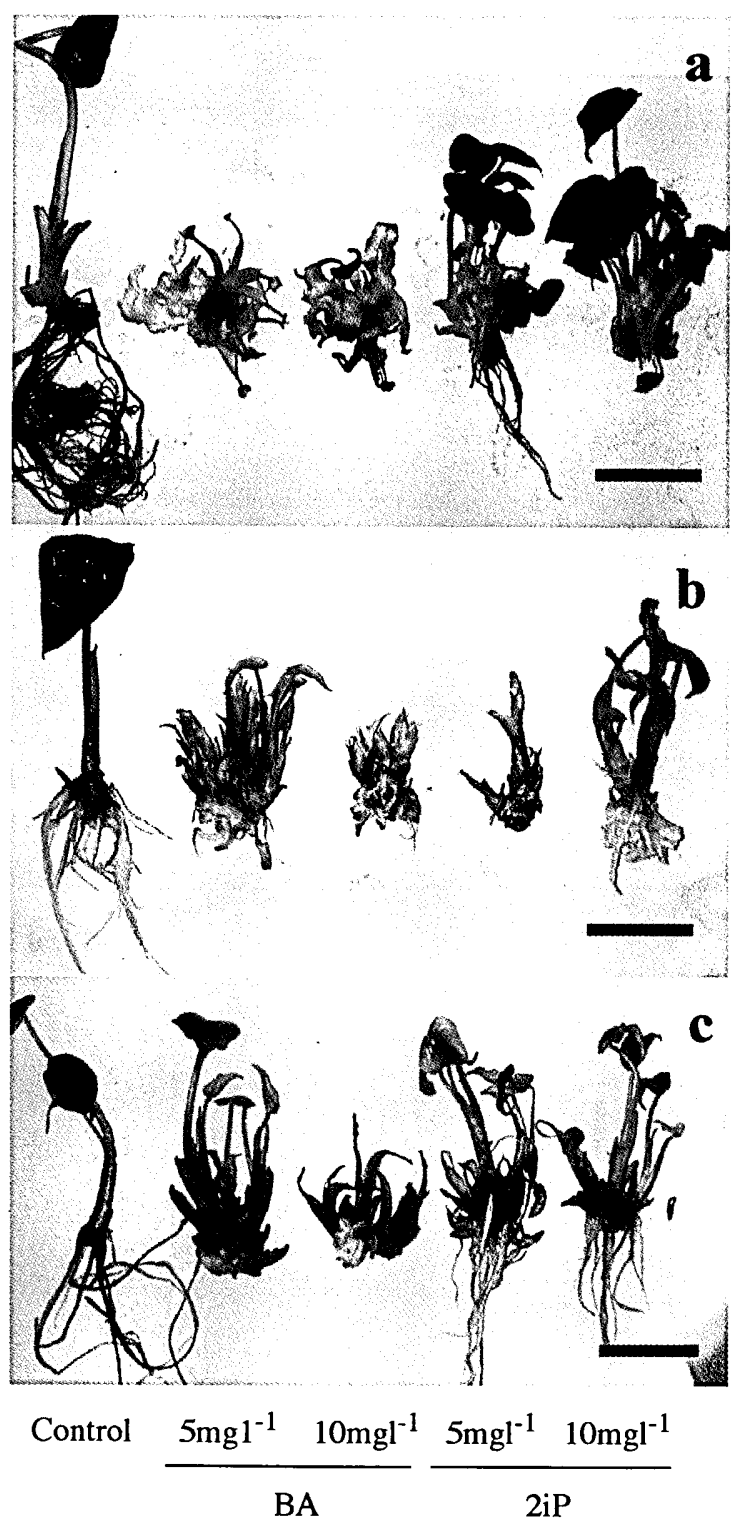

Fig. 1. Organogenetic response of $A$. micholitziana 'Green Velvet' (a), $A . \times$ amazonica (b) and A. cuculata (c) on MS medium supplemented with various concentrations of $\mathrm{BA}$ or $2-\mathrm{iP}$. Scale $\mathrm{bar}=2 \mathrm{~cm}$. 


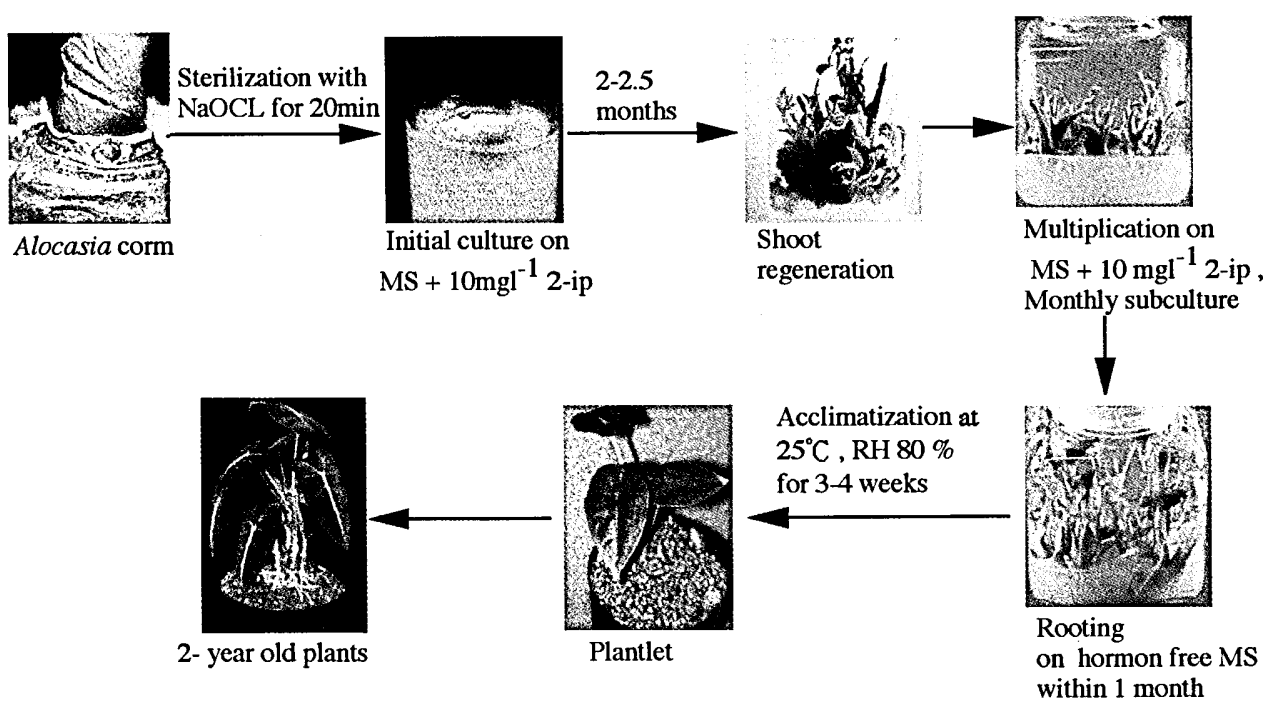

Fig. 2. Micropropagation procedure for A. micholitziana 'Green Velvet'.

\section{Rooting and acclimatization}

Rooting was simply induced by transferring the shoots onto MS medium without adding any kind of auxin. The acclimatization can be successfully achieved in all Alocasia with survival rate up to $100 \%$.

\section{Procedure for Alocasia multiplication}

A general protocol for the in vitro propagation of Alocasia would consist of the following steps (Fig. 2); adventitious buds or shoot tips from the corms of the original plants can be used as explants. The explants can then be cultured on MS+10 $\mathrm{mgl}^{-1} 2$-iP (in case of $A$. micholitziana 'Green Velvet') or $10 \mathrm{mgl}^{-1} \mathrm{BA}$ (in case of $A$. $\times$ amazonica and $A$. cuculata) for primary shoot regeneration. Regenerated shoots then can be transferred onto MS medium supplemented with $10 \mathrm{mgl}^{-1}$ 2-iP for $A$. micholitziana 'Green Velvet' or $5 \mathrm{mgl}^{-1}$ BA for $A$. $\times$ amazonica and $A$. cuculata for shoot multiplication. Root formation of isolated shoots can take place on MS medium without growth regulators. Initially high moisture conditions are needed for the acclimatization of in vitro plants before transfer to greenhouse.

It has been proved in vitro culture to be an efficient method for mass propagation of three Alocasia species/cultivars investigated. The established protocol provides a basic technique to carry out the furture in vitro experiements in Alocasia.

\section{REFERENCES}

Broertjes, C. and A. A. M. Van Harten 1978 Application of mutation breeding methods in the improvement of vegetatively propagated crops. Elsevier, Amsterdam

Geier, T. 1986 Factors affecting plant regeneration from leaf segments of Anthurium scherzerianum 
Schott (Araceae) cultured in vitro. Plant Cell, Tiss. Org. Cult., 6: 115-125

Hutchinson, M. J., J. M. Tsujita and P. K. Saxena 1994 Callus induction and plantlet regeneration from mature zygotic embryos of a tetraploid Alstroemeria (A. pelegrina $\times$ A. psittacina). Plant Cell Rep., 14: 184-187

Ibrahim, R., W. Monderlaers and P. C. Debergh 1988 Effects of X-irradiation on adventitious bud regeneration from in vitro leaf explants of Rosa hybrida. Plant Cell, Tiss. Org. Cult., 54: 37-44

Lin, H. S., C. van der Toorn, K. J. J. M. Raemakers, R. G. F. Visser, M. J. De Jeu and E. Jacobsen 2000 Development of a plant regeneration system based on friable embryogenic callus in the ornamental Alstroemeria. Plant Cell Rep., 19: 529-534

Murashige, T. and F. Skoog 1962 A revised medium for rapid growth and bioassays with tobacco tissue cultures. Physiol. Plant., 15: 473-497 